\title{
STRATEGI DAN METODE MENGHAFAL AL-QUR'AN DI PONDOK TAHFIDZ DARUL ITQON LOMBOK TIMUR
}

\author{
Junita Arini' ${ }^{1}$ Winda Wahyu Widawarsih ${ }^{2}$ \\ 1,2Universitas Islam Negeri Mataram \\ 1Email: junitaarini3@gmail.com \\ ${ }^{2}$ Email: windawidawarsih02@gmail.com
}

\begin{abstract}
Abstrak: Penelitian ini menggunakan Metode kualitatif. Jenis penelitian yang digunakan adalah studi kasus. Jenis data penelitian berupa catatan lapangan, dokumentasi dan foto. Teknik pengumpulan data melalui observasi, wawancara dan dokumentasi. Teknik analisis data deskriptif dengan cara memilah-milah data, mengklarifikasi data, dan menginterpretasikan data yang ditemukan di lapangan sehingga lebih mudah untuk menarik sebuah kesimpulan. Hasil penelitian dan pembahasan penelitian ini yaitu: (1) Strategi menghafal Alquran di Pondok Tahfizh Darul Itqon Bilasundung adalah dengan strategi pengulanagan per 1 juz, 3 juz, dan muraja'ah kelompok, pembiasaan menggunakan satu jenis mushaf, selalu memperhatikan ayat yang serupa, tidak berpindah ayat sebelum ayat yang dihafalkan benar-benar hafal, selanjutnya disetorkan kepada seorang pengampu. (2) Metode menghafal Alquran di Pondok Tahfizh Darul Itqon Bilasundung adalah metode wahdah, metode sima'i, menggabung hafalan baru dengan yang lama, membuat target hafalan, semaan dengan sesama teman hafizh, dan memperbanyak membaca Alquran. (3) Faktor-faktor yang menjadi penghambat dan pendukung dalam menghafal Alquran di Pondok Tahfizh Darul Itqon Bilasundung, (a) Faktor penghambat mengahfal Alquran di Pondok Tahfizh Darul Itqon adalah tidak menguasai makbraj dan tajwid, jarang muraja'ah, tidak bisa membagi waktu antara sekolah dengan menghafal, rasa malas, dan kurang konsentrasi. (b) Faktor pendukung menghafal Alquran di Pondok Tahfizh Darul Itqon adalah kesadaran diri sendiri yang meliputi cita-cita menjadi hafizh Alquran dan keinginan membalas jasa orang tua serta motivasi yang meliputi dorongan orang tua dan nasihat berharga dari pimpinan pondok Tahfizh Darul Itqon.
\end{abstract}

Kata Kunci: Strategi, Metode, Menghafal Al-Qur'an. 


\section{PENDAHULUAN}

Menghafal Alquran merupakan suatu perbuatan yang sangat terpuji dan sangat mulia. Orang-orang yang mempelajari Alquran, membaca atau menghafal Alquran merupakan orang-orang pilihan yang memang dipilih oleh Allah untuk menerima warisan kitab suci Alquran. Menghafal Alquran adalah kebiasaan sekaligus ciri orang yang diberi ilmu. Dengan tidak merasa jemu mereka terus mengisi sebagian waktunya setiap hari untuk menghafal dan mengulang-ulang hafalannya. Allah pun menegaskan dalam surah Al-Ankabut [29] : 49 : "Sebenarnya Alquran itu adalah ayat-ayat yang nyata di dalam dada orang-orang yang diberi ilmu. Dan tidak ada yang mengingkari ayat-ayat kami, kecuali orang-orang yang zalim."1

Menghafal Alquran juga merupakan sarana mengasah otak, mempertajam daya ingat, sekaligus antitesis terhadap kejenuhan membaca Alquran (bin-nadzar). Orang yang menghafal Alquran tidak akan merasa jemu membaca Alquran, memuraja'abnya sampai kerongkongan kering, suara serak, dan terkadang hingga mulut berbusa. Ini adalah amal yang berpahala besar di sisi Allah swt. karena merekalah sejatinya yang patut mendapat syafaat Alquran pada hari kiamat karena ketika di dunia mereka telah banyak membaca Alquran dengan segala kesungguhan. Sebagaimana yang disabdakan oleh Nabi Muhammad saw:

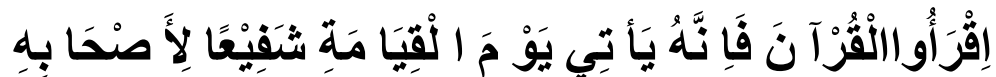

"Bacalah Alquran karena ia akan datang pada hari kiamat sebagai pemberi syafaat kepada para ablinya." (HR Muslim).2

Alquran diterima oleh Nabi Muhammad saw. melalui perantara malaikat Jibril dalam bentuk bunyi. Setelah itu, selang beberapa tahun barulah Alquran berubah menjadi bentuk tulisan setelah Nabi Muhammad saw. mendiktekannya kepada para sahabat yang menulis wahyu. Seperti yang telah diketahui bahwa Alquran diturunkan kepada Nabi Muhammad saw. secara berangsur-angsur selama 23 tahun. Proses turunnya Alquran secara berangsur-angsur dimaksudkan untuk lebih memudahkan menghafal dan memaknai maknanya. ${ }^{3}$

Ketika wahyu turun, Rasulullah saw. berupaya untuk menghafalkannya mulai dari bunyi, kata, panjang-pendek, kalimat, waqaf, dan unsur suprasegmental lainnya. Untuk mengomfirmasikan kemurnian Alquran setiap tahun pada bulan ramadhan

1Departemen Agama RI, AL-Qur'an..., hlm. 321.

141.

2Irfan Supandi, Agar Bacaan Alquran Tak Sia-Sia, (Solo: Tiga Serangkai, 2013), cet 1, hlm. 1, hlm. 136.

${ }^{3}$ Ahmad Sayuti Anshari Nasution, Fonetik dan Fonologi Al-qur'an, (Jakarta: Amzah, 2012), cet 
malaikat Jibril selalu mengadakan sima'an dengan Rasulullah saw. Setelah beliau menguasai semua unsur tersebut dengan baik, beliau menyampaikannya kepada para sahabat dan mereka menghafalkannya. Para sahabat juga melakukan hal yang sama kepada murid-murid mereka. Tabi'in juga melakukan cara dan hal yang sama. Demikian seterusnya sampai ke zaman sekarang ini. Upaya menghafal Alquran tidak pernah terputus dari generasi ke generasi. ${ }^{4}$

Hingga saat ini sudah banyak sekali para penghafal Alquran, mulai dari yang berusia anak-anak, remaja, hingga dewasa. Ada yang berprofesi sebagai polisi mampu menghafal Alquran, ada yang berprofesi sebagai seorang guru mampu menghafal Alquran, ada yang masih menginjak sekolah dasar juga sudah mulai menghafal Alquran, hal demikian membuktikan bahwa menghafal Alquran bukanlah perkara usia dan profesi, menghafal Alquran bukan pula perkara yang sulit. Sebagaimana dalam Firman Allah swt. dalam surah Al Qomar [54]: 17, 22, 32, dan 40.

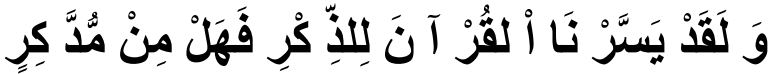

"Dan sesunggubnya telah Kami mudabkan Alquran untuk pelajaran, maka adakah orang yang mengambil pelajaran."

Dalam surah Al Qomar ayat ini diulang sebanyak 4 kali, Allah menegaskan bahwa bagi orang yang menghafal Alquran akan senantiasa diberi kemudahan. Ayat ini juga menjelaskan bahwa mempelajari Alquran bukanlah suatu perkara yang sulit, Allah telah memberikan kemudahan bagi setiap orang yang ingin mempelajarinya, Allah memberikan kemudahan bagi setiap orang yang ingin menghafalkannya. Terlebih pada saat ini, ilmu dan tekhnologi sudah berkembang dengan pesat, sehingga akan senantiasa memudahkan generasi yang ingin mempelajari dan menghafal Alquran. Kecanggihan ilmu tekhnologi dapat dengan mudah dimanfaatkan oleh siapa saja dan di mana saja dengan keinginan yang serius. Menghafal Alquran memiliki banyak sekali keutamaan yang tentunya dapat dijadikan sebagai motivasi bagi para penghafal Alquran. Menghafal Alquran juga merupakan suatu ibadah yang sangat terpuji.

Untuk dapat menghafal Alquran dengan baik, tentunya memerlukan strategi, metode dan taktik agar dapat mempertahankan hafalan yang telah diperjuangkan, seorang penghafal Alquran harus selalu mengulang hafalannya (Muraja'ah) setiap hari, mampu mengatur waktu untuk selalu menyempatkan diri mengulang hafalan.

${ }^{4}$ Ibid., hlm. 139.

5Departemen Agama RI, AL-Qur'an..., hlm. 423. 
Seorang penghafal Alquran memiliki strategi yang berbeda-beda dalam menghafal dan mempertahankan hafalan yang dimiliki. Agar hafalan Alquran tidak mudah hilang, banyak sekali hal-hal yang harus diperhatikan yaitu bagaimana amalan pra hafalan, hal-hal apa saja yang perlu diperhatikan dalam proses menghafal, apa saja yang perlu dilakukan untuk mempertahankan hafalan, apa saja yang dapat merusak hafalan, strategi, metode maupun taktik yang dapat diterapkan dalam menghafal Alquran.

Di Indonesia sudah banyak sekali lembaga nonformal yang bertujuan untuk mencetak generasi penghafal Alquran, berbagai macam lembaga yang telah ada juga menggunakan strategi dan metode yang berbeda-beda dalam proses menghafal Alquran, salah satu metode yang paling populer pada saat ini adalah metode AtTaisir yang di gagaskan oleh Ustadz Adi Hidayat yaitu 30 hari hafal Alquran. Dalam buku Ustadz Adi Hidayat yang berjudul Muslim Zaman Now, Metode At-Taisir 30 hari hafal Alquran, buku tersebut berupaya menampilkan petunjuk dengan cara sederhana, mudah dipahami. Isinya bahkan menghadairkan simulasi demi memudahkan praktek hafalan yang ingin diraih dengan cara seksama, dalam tempo sesingkat-singkatnya, yaitu 30 hari hafal Alquran. ${ }^{6}$

Pondok Tahfidz Darul Itqon merupakan salah satu lembaga pendidikan nonformal yang di pimpin oleh TGH. Muhammad Asroni Lc. Dan Ustadz Danang Sri Ujung Nurbuanto, S.Pd yang selalu berupaya mendidik para santrinya untuk menjadi para penghafal Alquran yang mampu mempelajari Alquran dan dapat menerapkan hikmah-hikmahnya dalam kehidupan sehari-hari. Rumah Tahfizh Darul Itqon berdiri pada bulan januari tahun $2015 .^{7}$

Kegiatan menghafal Alquran di pondok tahfizh Darul Itqon berlangsung selama 4 hari di dalam satu minggu, dimulai pada hari senin hingga hari kamis, dari sore hari hingga menjelang magrib. Kegiatan yang berlangsung pada hari senin hingga rabu merupkan kegiatan setoran hafalan dan muraja'ah kelompok dengan membawa map setoran berwarna hijau, sedangkan pada hari kamis kegiatan muraja'ah untuk hafalan 3 juz lebih. Kegiatan setoran berlangsung secara tertib, satu per satu siswa bergantian menyetorkan hafalan kepada pengampu, setelah selesai kegiatan setoran, santri berkumpul sesuai dengan kelompok dan melakukan muraja'ah kelompok. ${ }^{8}$ Berdasarkan latar belakang tersebut peneliti tertarik untuk hlm. xvi.

${ }^{6}$ Adi Hidayat, Muslim Zaman Now, (Jawa Barat: Institut Quantum Akhyar, 2018), cet ke-7,

7TGH. Muhammad Asroni Lc, Wawancara, Bilasundung, selasa 27 Agustus 2019.

${ }^{8}$ Observasi, Bilasundung, 27 Agustus 2019. 
melakukan penelitian terkait Strategi dan Metode Menghafal Alquran di Pondok Tahfizh Darul Itqon Bilasunsung, Desa Paokmotong, Kecamatan Masbagik, Kabupaten Lombok Timur.

\section{METODE PENELITIAN}

Penelitian ini menggunakan pendekatan kualitatif. Menurut Bogdan dan taylor sebagaimana dikutip oleh Lexy J. Moleong, "Metodologi kualitatif sebagai prosedur penelitian yang menghasilkan data deskriptif berupa kata-kata tertulis atau lisan dari orang-orang dan perilaku yang dapat diamati." Penelitian yang dilakukan bertujuan untuk mengetahui tentang strategi dan metode menghafal Alquran di Pondok Tahfizh Darul Itqon, penelitian dilakukan dengan cara mengamati peristiwa yang terjadi dalam sebuah kasus, obyek penelitiannya hanya di satu tempat dan kegiatannya masih berlangsung serta bersifat mendalam yaitu hanya di Pondok Tahfizh Darul Itqon Bilasundung Desa Paokmotong Kecamatan Masbagik Kabupaten Lombok Timu. Penelitian kualitatif dengan pendekatan studi kasus ini dianggap lebih refresentative dan akurat dalam menjawab fenomena yang berkaitan dengan strategi dan metode menghafal Alquran.

Teknik pengumpulan data merupakan langkah yang paling strategis dalam penelitian, karena tujuan utama dari penelitian adalah untuk mendapatkan data. Tanpa mengetahui teknik pengumpulan data, maka peneliti tidak akan mendapatkan data yang memenuhi standar data yang telah ditetapkan. ${ }^{10}$ Pengumpulan data dalam penelitian ilmiah adalah prosedur yang sistematis untuk memperoleh data yang diperlukan. Dalam penelitian kualitatif teknik pengumpulan data dapat dilakukan melalui setting dari berbagai sumber, dan berbagai cara. ${ }^{11}$ Adapun teknik pengumpulan data yang peneliti gunakan dalam penelitian ini adalah teknik observasi, wawancara dan dokumentasi. cet 29 , hlm. 4.

${ }^{9}$ Lexy J. Moleong, Metodologi Penelitian Kualitatif, (Bandung: PT Remaja Rosdakarya, 2011), hlm. 224

11Djam'an Satori \& Aan Komariah, Metodologi Penelitian Kualitatif, ( Bandung: ALFABETA, 2014), cet ke-6, hlm. 103. 


\section{TEMUAN DAN PEMBAHASAN}

\section{Strategi Menghafal Alquran}

Strategi merupakan suatu cara atau pola yang telah direncanakan dan ditetapkan secara sengaja sebelum melakukan suatu kegiatan atau tindakan. ${ }^{12}$ Dalam hal menghafal Alquran yang dimaksud strategi adalah bagaimana cara yang efektif dalam menghafal Alquran, mulai dari syarat menghafalan Alquran, menghafal maupun cara menjaga hafalan. ${ }^{13}$ Strategi juga disebut sebagai suatu taktik atau cara dalam melakukan sesuatu untuk mencapai suatu tujuan tertentu. ${ }^{14}$

Untuk membantu mempermudah membentuk kesan dalam ingatan terhadap ayat-ayat Alquran yang dihafal, maka diperlukan strategi menghafal yang baik. Strategi itu antara lain adalah sebagai berikut: ${ }^{15}$

1. Strategi pengulangan ganda

Untuk mencapai tingkat hafalan yang baik tidak cukup dengan sekali proses menghafal saja. Salah besar apabila seseorang menganggap dan berharap dengan sekali menghafal saja kemudia ia menjadi seorang yang menghafal Alquran dengan baik. Sebagaimana dalam hadis Rasulullah saw. dalam buku Ahsin W. Al-Hafidz yang mengatakan "Ayat-ayat Alquran itu lebih gesit daripada unta, dan lebih mudah lepas daripada unta yang diikat". ${ }^{6}$ Oleh sebab itu diperlukan sistem pengulangan ganda.

Umpamanya, jika pada waktu pagi hari telah mendapatkan hafalan satu halaman maka untuk mencapai tingkat kemapamanan hafalan yang mantap, perlu pada sore harinya diulang kembali menghafalnya satu per satu ayat yang telah dihafalnya di pagi hari. Semakin banyak pengulangan maka semakin kuat pelekatan hafalan dalam ingatannya, lisan pun akan membentuk gerak refleks sehingga seolah-olah tidak berpikir lagi untuk melafalkannya.

2. Tidak beralih pada ayat berikutnya sebelum ayat yang sedang dihafal benarbenar hafal

Kecenderungan para penghafal Alquran ialah ingin menghafal sebanyakbanyaknya dalam waktu yang singkat. Itulah yang menyebabkan hafalan Alquran menjadi tidak baik. Karena di dalam Alquran ada ayat-ayat yang mudah dihafal dan ada juga yang sulit untuk dihafalkan. Oleh karena itu dalam

12Abdul Majid, Strategi Pembelajaran, (Bandung: PT Remaja Rosdakarya, 2013), hlm. 3.

${ }^{13}$ Ahsin W Al-Hafidz, Bimbingan..., hlm. 63-66.

${ }^{14}$ Muhammad Asy'ari, Konsep Pendidikan Islam, (Jakarta: Rabbani Press, 2011), cet 1, hlm. 22.

${ }^{15}$ Ahsin W Al-Hafidz, Bimbingan..., hlm. 67-73.

${ }^{16}$ Ibid. 
menghafal Alquran diperlukan ketelitian dan kecermatan dalam mengamati tiap-tiap kata dan kalimat yang akan dihafalnya.

Menghafal Alquran harus benar-benar tekun meskipun ada ayat yang belum dihafal, tidak beralih kepada ayat lain sebelum dapat menghafal ayat yang sedang dihafalnya. Ayat yang sulit dihafal biasanya akan bisa dikuasai jika diulang berkali-kali, hal itu juga akan membuat hafalan lebih kuat.

3. Menggunakan satu jenis mushaf

Menghafal Alquran lebih baik menggunakan satu jenis mushaf. Meskipun tidak ada keharusan menggunakan satu jenis mushaf, namun jika menggunakan lebih dari satu mushaf dapat membingungkan pola hafalan yang telah dibentuk dalam bayangannya. Untuk itu akan lebih membawa banyak keuntungan jika menghafal Alquran menggunakan satu jenis mushaf.

4. Memahami (Pengertian) ayat-ayat yang dihafalkannya

Memahami pengertian, kisah atau asbabun-nu₹ul yang terkandung dalam ayat yang sedang dihafalnya merupakan unsur yang sangat mendukung dalam proses menghafal Alquran. Memahami itu sendiri akan lebih memberi arti bila didukung dengan pemahaman terhadap makna kalimat, tata bahasa dan struktur kalimat dalam suatu ayat. Dengan demikian maka penghafal yang menguasai bahasa Arab dan memahami struktur bahasanya akan lebih banyak mendapatkan kemudahan daripada mereka yang tidak mempunyai bekal penguasaan bahasa arab sebelumnya. Dan dengan cara seperti ini, maka pengetahuan tentang ulumul Quran akan banyak sekali terserap oleh para penghafal ketika dalam proses menghafal Alquran.

5. Memperhatikan ayat-ayat yang serupa

Ditinjau dari aspek makna, lafal dan susunan atau struktur bahasanya di antara ayat-ayat dalam Alquran banyak yang terdapat keserupaan atau kemiripan antara satu dengan yang lainnya. Ada yang benar-benar sama, ada yang hanya berbeda dalam dua, atau tiga huruf saja, ada juga yang hanya berbeda susunan kalimatnya saja. Sebagaimana dalam surah Az-Zumar [39] : 23.

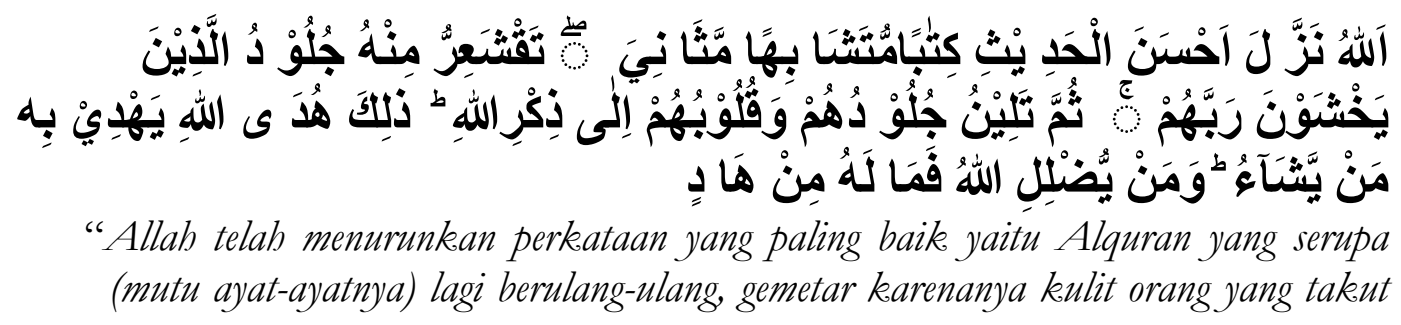


kepada Tuhannya, kemudian menjadi tenang kulit dan hati mereka di waktu mengingat Allah." 17

Adanya ayat-ayat yang serupa bukan hanya memberikan hambatan, namun juga ayat yang serupa memberikan keuntungan dalam proses menghafal Alquran, karena: Cepat dalam proses penghafal Alquran karena apabila terdapat satu ayat yang menyerupai penggal ayat lainnya, atau mungkin benar-benar sama kalimatnya, sehingga hanya perlu mengulang ayat tersebut beberapa kali saja, karena sebelumnya pernah dihafalkan; Banyaknya pengulangan terhadap ayat-ayat yang telah dihafalkannya seorang yang hafal Alquran akan menyimpulkan berbagai macam illat dan hukum yang berkaitan dengan perbedaan ayat-ayat yang serupa, dalam bentuk maupun dalam kandungan isinya.

Adanya keserupaan atau kemiripan ayat berarti telah memberikan keuntungan yang lebih, karena dengan menghafal satu ayat berarti telah memperoleh hasil dua, tiga, atau empat bahkan sampai lima ayat yang serupa dalam Alquran.

6. Disetorkan pada seorang pengampu

Dalam menghafal Alquran peran seorang pembimbing sangatlah penting, seorang pengampu, bertugas untuk menyimak setoran hafalan baru, atau takrir, yakni pengulangan kembali ayat-ayat yang telah disetorkannya terdahulu. Setoran kepada seorang pengampu menggunakan dua sistem yang biasa digunakan dalam program menghafal Alquran, yaitu: sistem tradisional pesantren dan sistem klasikal, atau terprogram.

Sistem pembinaan tradisional pesantren memiliki kualitas bimbingan yang lebih intensif, mendapat perhatian dari pembimbing lebih besar, dan sistem pembinaan tradisional lebih banyak tatap muka untuk setoran dan takrir. Dalam sistem setoran untuk menambah hafalan baru dapat dilakukan setiap hari, dengan syarat mengulang hafalan sebelumnya terlebih dahulu

Banyaknya pertemuan dengan pengampu tentunya mempunyai keuntungan pagi seorang penghafal Alquran. Ini dimaksudkan: Agar jika terjadi sebuah kesalahan dalam menghafal, Pengampu dapat segera meluruskan kesalahan tersebut sebelum terjadi pengendapan lebih lama, karena kesalahan menghafal yang telah terlanjur lama mengendap akan sulit untuk diluruskan;

\footnotetext{
${ }^{17}$ Departemen Agama RI, Al-Quran,... hlm. 368.
} 
Hafalan yang didengarkan kepada pengampu akan berbeda dengan hafalan yang tidak disetorkan kepada pengampu. Oleh sebab itu, pertemuan yang rutin dengan pengampu dapat membentuk hafalan yang baik dan kuat.

\section{Metode Menghafal Alquran}

Metode berasal dari bahasa yunani, meta, metodos, dan logos. Meta berarti menuju, melalui, dan mengikuti. Metodos berarti jalan atau cara. Maka metodos (metoda) berarti jalan atau cara yang harus dilalui untuk mencapai sesuatu. Metode adalah cara atau jalan bagaimana kita mengungkapkan suatu permasalahan melalui penelitian dan metode juga bisa dikatakan sebagai sudut pandang. ${ }^{18}$

Ada beberapa metode yang bisa dikembangkan dalam rangka mencari alternative terbaik untuk menghafal Alquran dan bisa memberikan bantuan kepada para penghafal dalam mengurangi kesulitan dalam menghafal Alquran. Metodemetode itu antara lain ialah: ${ }^{19}$

\section{Metode (Thariqab) Wabdah}

Yang dimaksud dengan metode wabdah, yaitu menghafal satu per satu terhadap ayat-ayat yang hendak dihafalnya. Untuk mencapai hafalan awal, setiap ayat bisa dibaca ayat sebanyak sepuluh kali, atau dua puluh kali, atau lebih sehingga proses ini mampu membentuk pola dalam bayangannya. Dengan demikian penghafal akan mampu mengkondisikan ayat-ayat yang dihafalkannya bukan saja dalam bayangannya, akan tetapi hingga benar-benar membentuk gerak reflex pada lisannya. Setelah benar-benar hafal barulah dilanjutkan pada ayat-ayat berikutnya dengan cara yang sama, demikian seterusnya hingga mencapai satu muka.

Setelah ayat-ayat dalam satu muka telah dihafalnya, maka gilirannya menghafal urutan-urutan ayat dalam satu muka. Untuk menghafal yang demikian maka langkah selanjutnya ialah membaca dan mengulang-ulang hingga mampu memproduksi ayat-ayat dalam satu muka tersebut secara alami, atau refleks. Demikian selanjutnya, sehingga semakin banyak diulang maka kualitas hafalan akan semakin representative.

2. Metode (Thariqah) Kitäbah

Metode kitabah adalah metode menghafal Alquran dengan cara menulis terlebih dahulu ayat yang hendak dihafalkannya. Sebelum menghafal dalam

\footnotetext{
${ }^{18}$ Rendra Khaldun, Pengantar Metodologi Studi Islam, (Mataram: Institut Agama Islam Negeri, 2016), hlm. 11.

${ }^{19} \mathrm{Ahsin}$ W Al-Hafidz, Bimbingan..., hlm. 63-66.
} 
metode ini penghafal menulis terlebih dahulu ayat yang akan dihafalnya pada sebuah kertas, dengan berkali-kali menulis ayat yang akan dihafalkan, tentunya akan mempengaruhi ingatannya dalam menghafal ayat tersebut. Metode ini sangat baik, karena dapat mengaktifkan fungsi audio dan juga visual.

\section{Metode (Thariqab) Sima'i}

Metode sima'i adalah metode menghafal Alquran dengan cara mendengarkan ayat-ayat yang akan dihafalkan. Metode ini sangat efektif bagi penghafal tunanetra, atau anak yang belum bisa baca tulis Alquran, serta bagi penghafal yang mempunyai daya ingatan kuat. Metode sima’i dapat dilakukan dengan dua cara: Mendengarkan ayat Alquran dari pembimbing, pembimbing terlebih dahulu membacakan ayatnya, baru kemudian diikuti oleh para santri hingga hafal dan beralih ke ayat berikutnya; Merekam terlebih dahulu ayat yang akan dihafalkan, kemudian didengarkan berulang kali sembari memperhatikan bunyi ayat tersebut hingga berkali-kali sampai akhirnya hafal, setelah hafal baru kemudian berpindah ke ayat selanjutnya. Metode ini sangat efektif bagi penghafal tunanetra, atau anak yang belum bisa baca tulis Alquran, atau untuk penghafal Alquran yang ingin mentakrir (mengulang kembali) ayat-ayat yang sudah dihafalkannya.

4. Metode (Thariqah) Gabungan

Metode gabungan adalah metode yang menggunakan gabungan dari metode wahdah dan metode kitabah. Namun dalam metode gabungan ini metode kitabah dijadikan sebagai bahan ujian bagi penghafal Alquran. Seorang penghafal Alquran yang telah selesai membacakan hafalannya kemudian diberikan ujian dalam bentuk menuliskan ayat-ayat yang telah dihaflkannya dalam sebuah kertas dengan sebuah hafalan pula. Jika telah mampu menuliskan ayat tersebut, maka ia bisa melanjutkan kembali hafalan berikutnya, tetapi jika penghafal belum mampu menuliskan ayat tersebut dengan baik, maka ia harus kembali menghafalkannya hingga benar-benar mampu menuliskannya dengan baik, demikian seterusnya.

5. Metode (Thariqah) Jama'

Metode jama' adalah metode menghafal Alquran yang dilakukan secara bersama-sama (kolektif) dan dipimpin oleh seorang instruktur. Instruktur membacakan satu ayat atau beberapa ayat dan santri menirukannya berulang- 
ulang hingga hafal. Setelah dapat membaca ayat tersebut dengan baik dan benar, selanjutnya mereka perlahan mencoba tanpa melihat mushaf dan demikian seterusnya. Adapun strategi menghafal Alquran menurut Wiwi Alawiyah Wahid dalam bukunya yang berjudul Cara cepat menghafal Alquran diantaranya adalah sebagai berikut: ${ }^{20}$

6. Metode menggabung antara mengulang hafalan pada hafalan lama dan menambah hafalan baru

Menghafal Alquran sebaiknya jangan tergesa-gesa, bahkan dilarang untuk menambah hafalan baru dengan tidak mengulang hafalan lama. Sebab, apabila secara rutin terus-menerus selalu menambah hafalan baru, tanpa mengulangi hafalan lama maka dikhawatirkan hafalannya banyak yang hilang. Oleh karena itu, metode yang paling baik dan tepat dalam menghafal Alquran ialah dengan menggabungkan antara mengulang dan menambah hafalan baru.

7. Membuat klasifikasi target hafalan

Target hafalan harus selalu dibuat oleh penghafal Alquran setiap harinya. Adanya target hafalan juga akan selalu membangkitkan semangat dan motivasi untuk selalu menyelesaikan target hafalan dengan baik. Apabila seorang pengahafal memiliki jadwal target hafalan tentu tidak akan ada waktu yang terbuang sia-sia.

8. Metode semaan dengan sesama teman tahfizh

Metode semaan dengan sesama teman hafizh adalah metode mentasmi' (memperdengarkan) hafalan kepada orang lain atau sesama teman hafizh, tujuannya agar dapat dikoreksi jika terjadi sebuah kesalahan. Mempunyai pasangan semaan sangatlah menyenangkan karena dengan semaan bersama teman tentu akan menghadirkan suasana yang nyaman dan santai. Sambil bersantai pun bisa melakukan semaan untuk memperkuat dan memperlancar hafalan.

9. Memperbanyak membaca Alquran sebelum menghafal

Memperbanyak membaca Alquran sebelum menghafalkannya. Merupakan metode cepat menghafal Alquran. Tujuannya, agan mengenal terlebih dahulu ayat-ayat yang hendak dihafalkan dan tidak asing lagi dengan ayat-ayat tersebut, sehingga lebih mudah menghafalkannya. Semakin sering membaca Alquran, maka akan semakin mudah dalam menghafalkannya.

20Wiwi Alawiyah Wahid, Cara Cepat Bisa Menghafal Alquran, (Jogjakarta: DIVA Press, 2014), cet VII, hlm. 81-103. 


\section{Strategi Menghafal Al-Quran di Pondok Tahfizh Darul Itqon}

Sesuai dengan artinya, menghafal berarti telah masuk kedalam ingatan, dapat diucapkan diluar kepala. Menghafal juga suatu kegiatan berulang-ulang dengan cara membaca maupun mendengar. menghafal tidak akan sukses jika tidak dibarengi dengan usaha dan semangat yang besar. Meskipun kemurnian Alquran telah dijamin oleh Allah swt., bukan berarti manusia dapat lepas tanggung jawab dari hal tersebut. Menghafal merupakan suatu bentuk partisipasi dalam menjaga kemurnian Alquran, karena hingga saat ini pun musuh-musuh Islam senantiasa berusaha mengusik kemurian Alquran dengan cara memalsukan isi-isinya agar tidak sesuai dengan ajaran Islam.

Seorang santri yang ingin meghafal Alquran tentu harus memperbagus bacaan Alqurannya terlebih dahulu, memperlancar bacaan, Makhraj, Ilmu tajwid, jadi menghafal bukan berarti hanya hafal ayatnya, namun harus sesuai dengan kaidahnya pula. Dalam hal ini seorang pengampu harus selalu memperhatikan kebutuhan para santri mulai dari membimbing, mengontrol, memotivasi dan sebagainya. Hal senada diutarakan oleh TGH M. Asroni, Lc:

"Santri yang ingin menghafal Alquran harus mampu membaca Alquran dengan baik dan benar, baru setelah itu dapat menghafal Alquran, karena jika membaca saja masih belum lancar, maka akan mempersulit juga dalam proses menghafal Alquran. Di sini awalnya juga kami kira semuanya sudah mampu membaca Alquran dengan baik, namun ternyata ada beberapa santri yang belum tepat dalam mengucapkan makhraj huruf dan belum tau tentang ilmu tajwid itu sebabnya santri tersebut kami buatkan program tahsin sebelum menyetorkan hafalannya."21

Dalam penghafal pendapat setiap orang akan berbeda-beda, ada yang mengatakan menghafal itu mudah, ada pula yang mengatakan menghafal itu sulit, sesuai dengan Firman Allah dalam surah Al Qomar [54]: 17, 22, 32, dan 40.

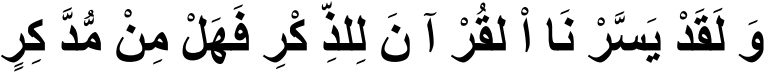

"Dan sesunggubnya telah Kami mudabkan Alquran untuk pelajaran, maka adakah orang yang mengambil pelajaran."22

Allah telah menjamin kemudahan bagi orang yang ingin mempelajari dan menghafal Alquran, ayat tersebut diulang sebanyak 4 kali untuk lebih meyakinkan betapa mudah dan diberi kemudahannya orang yang sungguh-sungguh dalam menghafal Alquran. Dalam menghafal Alquran kesulitan akan bisa teratasi dengan

21TGH Muhammad Asroni Lc,. Wawancara, Bilasundung, 5 Desember 2019.

${ }^{22}$ Departemen Agama RI, AL-Qur'an..., hlm. 423. 
menerapkan strategi-strategi dalam menghafal Alquran. Sebagaimana dalam buku Ahsin W. Al-Hafizh yang berjudul Bimbingan Praktis Menghafal Alquran yaitu: ${ }^{23}$

1. Pengulangan ganda

2. Tidak beralih pada ayat berikutnya sebelum ayat yang sedang dihafal benarbenar hafal

3. Menggunakan satu jenis mushaf

4. Memahami (Pengertian) ayat-ayat yang dihafalkan

5. Memperhatikan ayat-ayat yang serupa

6. Disetorkan pada seorang pengampu

Di pondok Tahfizh Darul Itqon strategi yang diterapkan adalah strategi pengulangan per 1 juz, 3 juz dan muraja'ah perkelompok, strategi ini bertujuan agar santri selalu dapat mempertahankan hafalan yang lama meskipun sedang menghafalkan yang baru, selain sebagai seorang santri, mereka juga berperan ganda sebagai seorang siswa, dari pagi hingga siang menjalankan kegiatan sekolah, siang mempersiapkan hafalan hingga sore, magrib mengaji dan malam baru bisa istirahat, program ini diadakan agar santri dapat selalu memuraja'ah hafalannya, agar mereka tidak hanya mendapatkan lelah tapi juga lillah.

Pada penerapannya menggunakan satu jenis mushaf sudah menjadi suatu keharusan bagi santri, karena sejak awal TGH Muhammad Asroni Lc. telah memberikan wejangan kepada santri perihal menghafal menggunakan satu mushaf. Tidak beralih kepada ayat berikutnya sebelum ayat yang sedang dihafal benar-benar hafal, Memperhatikan ayat yang serupa, merupakan suatu keharusan dalam menghafal Alquran, karena jika merasa belum hafal kemudian beralih keayat berikutnya tentu itu akan membebani santri lebih berat begitupun dengan ayat-ayat yang serupa, setiap santri harus selalu memperhatikan tiap-tiap ayat yang hendak dihafalkannya agar tidak ada kekeliruan dan pola yang salah dalam menghafal Alquran.

Di pondok tahfizh Darul Itqon pimpinan pondok mengharuskan para santri untuk menyetor hafalannya kepada pengampu hal itu dimaksudkan agar kekeliruan yang terjadi dapat diatasi, jikalau santri tidak menyetor akan ada kemungkinan santri tidak bersungguh-sungguh dalam menghafal Alquran. Segala strategi yang diterapkan di Pondok Tahfizh Darul Itqon merupakan strategi terbaik yang bertujuan untuk memberikan kenyamanan dan memenuhi kebutuhan para santri dalam menghafal Alquran.

\footnotetext{
${ }^{23} \mathrm{Ahsin}$ W Al-Hafidz, Bimbingan..., hlm. 67-71
} 
Strategi yang telah diterapkan di Pondok Tahfizh Darul Itqon dapat dikatakan sudah sangat baik dan efektif, hal itu dikarenakan saat ini sudah ada santri yang hafal 30 juz, meskipun sedang dalam proses muraja'ah kembali, strategi tersebut sudah membantu dalam proses mengahfal dan mempermudah santri dalam menjalankan peran gandanya sebagai siswa dan santri.

\section{Metode Menghafal Alquran di Pondok Tahfizh Darul Itqon}

Dalam menghafal Alquran metode yang hendak digunakan oleh para santri harus selalu diperhatikan oleh santri itu sendiri, santri harus tau menghafal cepat bagi dirinya menggunakan metode apa, dan metode apa yang tidak cocok bagi dirinya. Dalam hal ini Pondok Tahfizh akan selalu mendukung bagaimana pun metode yang digunakan santri dalam menghafal Alquran.

Metode yang digunakan santri dalam menghafal Alquran tentunya berbedabeda. Pimpinan dan pembimbing pondok memberikan kebebasan kepada para santri untuk menggunakan metode apa saja untuk menghafal Alquran. sebelum datang ke pondok santri terlebih dahulu menyiapkan hafalan di rumah masing-masing, sesampainya di Pondok santri akan bergantian satu per satu menyetorkan hafalan maupun muraja'ah kepada pengampu. Kegiatan menghafal berlangsung selama 2 jam dalam sehari. Sebagaimana yang dijelaskan oleh TGH Muhammad Aroni Lc selaku pembimbing:

"Seperti yang tadi tiang katakan, baik dari strategi maupun metode kami tidak mengharuskan santri menggunkan metode ini, tidak pula mengharuskan para santri menggunakan metode itu, kami membebaskan para santri nyamannya menggunakan metode apa, gampangnya menggunakan metode apa, baiknya menggunakna metode apa, namun seiring berjalannya program ini, biasanya santri sering menggunakan metode wahdah, metode sima'i dan tergantung dari kebiasan para santri, kami hanya memberikan arahan dan tetap mengontrol hafalan mereka." 24

Selain strategi menghafal Alquran yang diterapkan di Pondok Tahfizh Darul Itqon, ada juga metode menghafal Alquran yang dapat memudahkan santri dalam menghafal Alquran. Metode merupakan suatu cara yang dapat dipilih oleh seorang santri dalam mengahfal. Sebagaimana dalam buku Ahsin W. Al-Hafizh yang berjudul Bimbingan Praktis Menghafal Alquran yaitu:25

1. Metode (Thariqah) Wabdah

2. Metode (Thariqah) Kitabah

3. Metode (Thariqab) Sima'i

24TGH Muhammad Asroni Lc., Wawancara, Bilasundung, 5 Desember 2019.

${ }^{25}$ Ahsin W Al-Hafidz, Bimbingan..., hlm. 63-66. 
4. Metode (Thariqah) Gabungan

5. Metode (Thariqah) Jama'

Dalam buku Wiwi Alawiyah Wahid yang berjudul Cara Cepat bisa Megahafal Alquran adapula metode menghafal Alquran yaitu: ${ }^{26}$

1. Metode menggabung antara mengulang hafalan pada hafalan lama dan menambah hafalan baru

2. Membuat klasifikasi target hafalan

3. Metode semaan dengan sesama teman hafizh

4. Memperbanyak membaca Alquran sebelum menghafal

Dalam penerapannya pimpinan pondok menyarankan santri untuk menggunakan metode wahdah, metode sima'i, menggabungkan hafalan baru dengan yang lama, hal itu terlihat dari saran yang diberikan oleh TGH Muhammad Asroni Lc. dan penjelasan beberapa santri yang memperkuatnya, sedangkan untuk metode semaan dengan teman hafizh merupakan inisiatif santri itu sendiri.

Di pondok Tahfizh Darul Itqon metode wahdah merupakan suatu cara menghafal Alquran dengan cara membaca satu ayat secara berulang-ulang sebanyak 10-20 kali. Begitupun dengan metode sima'i yaitu menghafal dengan cara mendengarkan murotal dari imam besar yaitu seperti Syeikh Muhammad Ayub, Syeikh Muhammad Ali Huzaifi, dan Misyari Rasyid, menurut TGH Muhammad Aroni Lc, ketiga imam tersebut dapat dijadikan suri tauladan dalam menghafal Alquran, karena bacaannya yang sudah sangat bagus, mengedepankan makhraj dan tajwid, dan juga sudah menjadi imam besar. Metode-metode tersebut sudah berjalan dengan baik, sesuai dengan pengakuan para santri yang masih aktif dan pasif pada saat ini.

\section{Faktor Penghambat dan Pendukung dalam Proses Menghafal AlQur'an}

Dalam menjalankan suatu kegiatan, suatu penghambat akan selalu ada, seakan hambatan menjadi bumbu dan penentu apakah seorang santri mampu melewati hal tersebut atau tidak, sebagaimana penjelasan TGH Muhammad Asroni Lc sebagai berikut:

"Yang sering menjadi kendala dalam menghafal Alquran itu ya tentunya dari pribadi santrinya, kalau di pondok yang sering terlihat itu santri yang jarang hadir (Malas) tentu itu suatu masalah dalam menghafal, ketika mereka jarang hadir, yang menjadi pertanyaan di rumah apakah mereka menghafal atau muraja'ah, seandainya iyaa, tentu itu tidak akan menjadi masalah, namun karena kami tau santri terkadang kalau sudah di rumah ya palingan keluar main. jarang

${ }^{26}$ Wiwi Alawiyah Wahid, Cara..., hlm. 81-103. 
muraja'ah juga sangat menghambat dalam mengahfal, itu sebabnya kami adakan muraja'ah 1 juz, 3 juz dan muraja'ah kelompok." 27

Dalam menjalankan suatu kegiatan atau proses, penghambat dan pendukung akan selalu dirasakan oleh santri dalam hal menghafal Alquran, berbagai sisi akan selalu mempengaruhi proses menghafal Alquran, baik penghambat secara internal dan eksternal maupun pendukung secara internal dan eksternal

1. Faktor Penghambat dalam mengahfal Alquran

Faktor penghambat dalam menghafal Alquran dapat berasal dari santri itu sendiri maupun dari faktor orang lain maupun lingkungan, sesuai dengan pendapat Wiwi Alawiyah Wahid yang berjudul Cara Cepat bisa Mengahfal Alquran. ${ }^{28}$ Terkadang, problem dalam menghafal Alquran juga timbul dari diri sang penghafal itu sendiri. Problem-problem tersebut di antaranya ialah:

a. Tidak menguasai makhraj huruf dan tajwid

b. Tidak sabar

c. Tidak sunguh-sungguh

d. Tidak menghindari dan menjauhi maksiat

e. Tidak banyak berdoa

f. Tidak beriman dan bertakwa

g. Berganti-ganti mushaf Alquran

h. Ujub dan riya'

Dua penyakit ini mendapat perhatian serius dari para ulama, khususnya ahli Alquran. Sifat ujub dan riya' adalah senyawa batil yang mampu menghanyutkan ayat-ayat suci yang telah terpatri di jiwa. Keduanya sering kali ditanamkan setan kala penghafal Alquran mulai tampil di hadapan publik ataupun "Rajin bermusabaqah". Karena banyak penghafal Alquran yang terjerumus oleh sifat ujub dan riya'. ${ }^{29}$

i. Lupa

Problem lupa merupakan sesuatu yang dapat merugikan manusia. Dalam banyak keadaan lupa juga menghalangi manusia untuk melakukan penyesuaian yang tepat atas problematika kehidupan yang dihadapinya. ${ }^{30}$ Kecenderungan lupa pada diri manusia disebabkan setan menemukan jalan untuk memengaruhi manusia, kadang-kadang setan membuat

27TGH Muhammad Asroni Lc., Wawancara, Bilasundung, 5 Desember 2019.

28Ibid., hlm. 113-120.

${ }^{29}$ Adi Hidayat, Muslim..., hlm. 40.

${ }^{30}$ Muhammad Utsman Najati, Psikologi..., hlm. 338. 
manusia lupa akan persoalan penting yang mengandung kemaslahatan untuk dirinya. Setan juga kadang-kadang menjadikan manusia lupa mengingat Allah swt. serta mengabaikan ketaatan kepada perintahperintah Allah swt.

Selain problem yang muncul dari dalam diri penghafal, problem dalam menghafal Alquran juga banyak disebabkan dari luar dirinya, seperti:

a. Tidak ada pembimbing (Muwajjï). Muwajjih sangat penting di dalam proses menghafal Alquran. keberadaannya akan selalu memberi semangat kepada seorang penghafal. Ia juga bertugas mengontrol hafalan. Penghafal yang tanpa seorang pembimbing dapat dipastikan banyak mendapat kesulitan dalam menghafal, dan biasanya kalau sudah salah akan susah untuk diluruskan. ${ }^{31}$

b. Adanya kemiripan ayat-ayat yang satu dengan yang lainnya, sehingga sering menjebak, membingungkan, dan membuat ragu.

Di pondok Tahfizh Darul Itqon menurut TGH Muhammad Asroni Lc penghambat yang sering terjadi adalah ketika santri jarang hadir (Malas) dan tidak muraja'ah, sedangkan berdasarkan pengakuan santri yang paling sering menghambat proses mengahfal Alquran adalah ketika malas, tidak muraja'ah dan tidak bisa membagi waktu antara sekolah dan menghafal, hal tersebut tentu sering dirasakan oleh para santri selama menjalankan proses menghafal Alquran, untuk itu pimpinan dan pembimbing selalu mengupayakan agar semangat dalam menghafal selalu tertanam kuat dalam diri seorang santri.

2. Faktor pendukung dalam menghafal Alquran

Dalam menghafal Alquran seorang pemimpin dan pembimbing harus selalu bisa memberikan dukungan motivasi kepada setiap santri. Menurut S. Nasution, "Motivasi adalah menciptakan kondisi sedemikian rupa sehingga anak itu mau melakukan apa yang dapat dilakukannya. Adapun faktor pendukung juga pasti ada dalam setiap melakukan kegiatan, TGH Muhammad Asroni Lc. selaku pimpinan menjelaskan bahwa:

"Selama di pondok, santri menjadi anak-anak kami, kami berperan sebagai orang tua yang akan selalu membimbing, menasehati, memotivasi, dan mengontrol para santri, kalaupun tiang tidak bisa hadir, tentunya ustadz Danang akan selalu melakukan hal yang sama, apalagi santri-santri di sini masih belum dewasa dalam menyikapi segala sesuatu, galau sedikit pasti

${ }^{31}$ Abdul Aziz Abdul Rauf, Kiat..., hlm. 89. 
malas untuk menghafal, jadi kalau semangat mereka mulai kendor, kami mulai kembali untuk memberikan nasihat agar semangat lagi." 32

W. H Burton dalam bukunya "The guidance of Learning Activity" membedakan dua jenis motivasi yaitu 1) Motivasi instrinsik dan motivasi ekstrinsik. Metode intrinsik adalah suatu cita-cita atau daya yang telah ada dalam diri individu yang mendorong seseorang untuk berbuat dan melakukan sesuatu sedangkan motivasi ekstrinsik ialah segala sesuatu yang datang dari luar yang menjadi cemeti bagi murid-murid untuk berbuat lebih giat. ${ }^{33}$

Peran seorang pendidik, pembimbing sangat berpengaruh terhadap perkembnagan peserta didik atau santri, pembimbing yang mampu selalu memotivasi santrinya tentu akan menghasilkan santri yang berprestasi pula. Di pondok Tahfizh Darul Itqon, TGH Muhammad Asroni Lc. selaku motivator ekstrinsik selalu memberikan motivasi, wejangan, nasihat kepada setiap santrinya ketika santri terlihat mulai malas dan tidak bersemangat, dorongan orang tua juga selalu mampu menumbuhkan semangat anak untuk istiqomah menghafal Alquran, begitupun dengan motivasi instrinsik, santri harus memiliki kesadaran diri untuk tetap mengahfal Alquran dan sesuai juga dengan cita-cita para santri yang ingin menjadi penghafal Alquran (Hafizh).

\section{Hasil capaian hafalan santri pondok Tahfizh Darul Itqon Bilasundung Desa Paokmotong Kecamatan Masbagik Kabupaten Lombok Timur}

Dalam menghafal Alquran setiap santri ingin meraih julukan sebagai penghafal Alquran 30 juz, setiap santri menggunakan strategi dan metode yang berbeda, faktor penghambat dan pendukung yang dialami berbeda pula, hal tersebut dapat pula mempengaruhi hasil capaian dalam menghafal Alquran, ada santri yang mampu menghafal banyak dalam kurun waktu yang sedikt adapula yang sebaliknya. Sebagaimana penjelasan Ustadz Danang Sri Ujung Nurbuanto:

"Santri yang ada di pondok Tahfizh Darul Itqon merupakan santri yang berperan ganda, selain sebagai seorang santri mereka juga berperan sebagai seorang siswa, bersekolah dari pagi hingga siang hari, siang sampai sore mempersiapkan hafalan, itu salah satu alasan mengapa di pondok tidak diadakan penargetan untuk menghafal Alquran, seharusnya sih ada agar santri semakin bersemangat dalam menghafal, namun jika terlalu dipaksakan, santri

32TGH Muhammad Asroni Lc., Wawancara, Bilasundung, 5 Desember 2019.

${ }^{33}$ Ramayulis, Metodologi Pendidikan Agama Islam, (Jakarta: Kalam Mulia, 2014), hlm. 113. 
akan banyak yang tidak nyaman dan memilih berhenti menghafal, paling tidak santri bisa hafal Alquran 30 juz dengan target 4-5 tahun." 34

Hasil capaian hafalan yang didapatkan oleh santri tidak akan sesukses saat ini jika tidak dibarengi dengan usaha, doa dan dukungan dari berbagai pihak, setiap santri pasti ingin mejadi seorang penghafal Alquran 30 juz, itu merupakan salah satu tujuan dari menghafal Alquran. Sebagaimana dalam buku Muhammad Ngalim Purwanto yang berjudul Psikologi Pendidikan bahwa tujuan motivasi adalah untuk menggerakkan atau menggugah seseorang agar timbul keinginan dan kemauannya untuk melakukan sesuatu sehingga dapat memperoleh hasil atau mencapai tujuan tertentu. ${ }^{35}$

Di dalam menghafal Alquran motivasi tentunya sangat diperlukan untuk menumbuhkan semangat dalam menghafal Alquran, begitupun di Pondok Tahfizh Darul Itqon, santri yang lebih cepat hafal biasanya memiliki semangat yang lebih besar dalam menghafal Alquran begitupun sebaliknya dengan santri yang lama dalam menghafal selain faktor penghambat lainnya.

\section{KESIMPULAN}

Berdasarkan paparan data dan pembahasan pada bab-bab terdahulu, maka penelitian ini dapat peneliti simpulkan sebagai berikut: Strategi menghafal Alquran di Pondok Tahfizh Darul Itqon Bilasundung Desa Paokmotong Kecamatan Masbagik Kabupaten Lombok Timur adalah dengan strategi pengulanagan per 1 juz, 3 juz, muraja'ah kelompok, pembiasaan menggunakan satu jenis mushaf, keharusan untuk selalu memperhatikan ayat yang serupa, tidak berpindah ayat sebelum ayat yang dihafalkan benar-benar hafal, dan disetorkan kepada seorang pengampu. Metode menghafal Alquran di Pondok Tahfizh Darul Itqon Bilasundung Desa Paokmotong Kecamatan Masbagik Kabupaten Lombok Timur adalah metode wabdah, metode sima'i, menggabung hafalan baru dengan yang lama, membuat target hafalan, semaan dengan sesama teman hafizh, dan memperbanyak membaca Alquran.

Faktor-faktor yang menjadi penghambat dan pendukung dalam menghafal Alquran di Pondok Tahfizh Darul Itqon Bilasundung Desa Paokmotong Kecamatan Masbagik Kabupaten Lombok Timur; Faktor penghambat menghafal Alquran di Pondok Tahfizh Darul Itqon adalah tidak menguasai makhraj dan tajwid, jarang muraja'ah, tidak bisa membagi waktu antara sekolah dengan menghafal, rasa malas,

\footnotetext{
${ }^{34}$ Ustadz Danang Sri Ujung Nurbuanto, Wawancara, Bilasundung, 31 Desember 2019.

${ }^{35}$ Muhammad Ngalim Purwanto, Psikologi Pendidikan, (Bandung: PT Remaja Rosdakarya, 2011), hlm. 73.
} 
dan kurang konsentrasi; Faktor pendukung menghafal Alquran di pondok Tahfizh Darul Itqon adalah kesadaran diri sendiri yang meliputi cita-cita menjadi hafizh Alquran dan keinginan membalas jasa orang tua serta motivasi yang meliputi dorongan orang tua dan nasihat berharga dari pimpinan pondok Tahfizh Darul Itqon.

Hasil capaian hafalan santri di Pondok Tahfizh Darul Itqon Bilasundung Desa Paokmotong Kecamatan Masbagik Kabupaten Lombok Timur adalah bervariasi, hingga saat ini baru satu orang santri yang mampu menghafal 30 juz, santri yang lain memiliki kisaran hafalan antara 5-15 juz.

\section{DAFTAR PUSTAKA}

A. Muri Yusuf, Metode Penelitian Kuantitatif, Kualitatif \& Penelitian Gabungan. Jakarta: Kencana, 2014.

Abdul Aziz Abdul Rauf, Kiat Sukses Menjadi Hafidz, Quran Da'iyah. Bandung: PT Syaamil Cipta Media, 2004.

Abdul Majid, Strategi Pembelajaran. Bandung: PT Remaja Rosdakarya, 2013.

Adi Hidayat, Muslim Zaman Now. Jawa Barat: Istitut Quantum Akhyar, 2018.

Ahmad Munjin Nasih \& Lilik Nur Khoidah, Metode dan Teknik Pembelajaran Pendidikan Agama Islam. Bandung: PT Reflika Aditama, 2013.

Ahmad Sayuti Anshari Nasution, Fonetik dan Fonologi Al-qur'an. Jakarta: Amzah, 2012.

Ahsin W Al-Hafidz, Bimbingan Praktis Menghafal Al-Qur'an. Jakarta: Bumi Aksara, 2000.

Beni Ahmad Saebani, Metode Penelitian. Bandung: CV Pustaka Setia, 2008.

Departemen Agama RI, Alquran dan Terjemahnya, Jawa Barat: CV Penerbit Diponegoro, 2006.

Djam'an Satori \& Aan Komariah, Metodologi Penelitian Kualitatif. Bandung: ALFABETA, 2014.

Ibrahim Ibn Al Syaikh Shalih Ibn Ahmad Al Khuraishui, Pedoman Hidup Seorang Muslim, terj. W. Djunaedi. Jakarta: Pustaka Azzam, 2000.

Imam Abu Zakaria Yahya, Tarjamah Riadhus Shalibin jilid 2, Terj. Salim Bahraesy. Bandung: PT Alma'arif, 1997.

Imam An-Nawawi, Adab dan Tata Cara Menjaga Alquran. Jakarta: Pustaka Amani, 2001.

Imam An-Nawawi, Bersanding dengan Alquran, Terj. Abdul Aziz. Bogor: Pustaka Ulil Albab, 2007.

Imam Gunawan, Metode Penelitian Kualitatif Teori \& Praktik. Jakarta: Bumi Aksara, 2016.

Irfan Supandi, Agar Bacaan Alquran Tak Sia-Sia. Solo: Tiga Serangkai, 2013.

Izatul Umniyah, "Strategi Peningkatan Kualitas Hafalan Al-Qur'an Bagi Mahasiswa (Studi Kasus di PPTQ Putri Nurul Furqon Klojen Malang). Skripsi, UIN 
Maulana Malik Ibrahim Malang, Malang, 2018.

Kholidul Iman, "Strategi Menghafal Al-Qur'an Bagi Siswa (Studi Kasus di Rumah Tahfidz Daarul qur'an Putra Kepanjen Malang). Skripsi, UIN Maulana Malik Ibrahim Malang, Malang, 2016.

Khurram Murad, Membangun Generasi Qurani, Terj. Al Yupi. Jakarta: Media Da'wah, 1999.

Lexy J. Moleong, Metodologi Penelitian Kualitatif. Bandung: PT Remaja Rosdakarya, 2011.

Melly Taqdir Qodratillah, dkk, Kamus Bahasa Indonesia. Jakarta: Badan Pengembangan dan Pembinaan Bahasa, Kementrian dan Kebudayaan, 2011.

Muhammad Asy'ari, Konsep Pendidikan Islam. Jakarta: Rabbani Press, 2011.

Muhammad Ngalim Purwanto, Psikologi Pendidikan. Bandung: PT Remaja Rosdakarya, 2011.

M. Quraish Shihab, Membumikan Alquran. Bandung: Mizan, 2007.

Muhammad Utsman Najati, Psikologi dalam Alquran. Bandung: CV Pustaka Setia, 2005.

Muhammad Zaidi Abdad dkk, Sukses Membaca Alquran. Mataram: pusat pengembangan bahasa Institut Agama Islam Negeri, 2016.

Mukhlis, Pengantar Metodologi Studi Islam. Mataram: Lembaga Pengkajian-Publikasi Islam \& Masyarakat, 2015.

Ramayulis, Metodologi Pendidikan Agama Islam. Jakarta: Kalam Mulia, 2014.

Ridho Ali Al Idrus, "Efektivitas Pemebelajaran Tahfidzul Quran Di Pondok Pesantren Yusuf Abdussatar Kediri Lombok Barat. Skripsi, UIN Mataram, Mataram, 2013.

Rendra Khaldun, Pengantar Metodologi Studi Islam. Mataram: Institut Agama Islam Negeri, 2016. 